Aftershocks
India opens its doors
to international
earthquake research
$p 968$$\quad \begin{aligned} & \text { Divided fortunes } \\ & \text { Bush budget to boost } \\ & \text { bioscience but freeze } \\ & \text { physics } \\ & p 969\end{aligned}$

\title{
European Union moves to curb moratorium on transgenic plants
}

Quirin Schiermeier, Munich

In a bid to end the impasse that has effectively prevented transgenic crops from being grown on European farms, the European Union (EU) has adopted tighter rules for their use.

The biotechnology industry welcomed the new rules, which it hopes will eventually lead to the acceptance of genetically modified (GM) crops in Europe. Environmental groups were more circumspect, indicating that they would accept the rules as long as the ban on the technology was maintained.

But in a move that highlights the limits of the EU's jurisdiction, six states issued a statement saying they would keep the ban in place.

Following last week's ruling by the governing council, the $15 \mathrm{EU}$ member states have 18 months to implement the rules. In the meantime, the present de facto moratorium on the commercial planting of new transgenic crop varieties is likely to continue.

Under the new rules, suppliers of transgenic crop seeds must carry out strict assessments of environmental risk before the seeds can be licensed for use. If approved, the GM plants must be continually monitored for their environmental and health effects.

Local authorities and the public will be

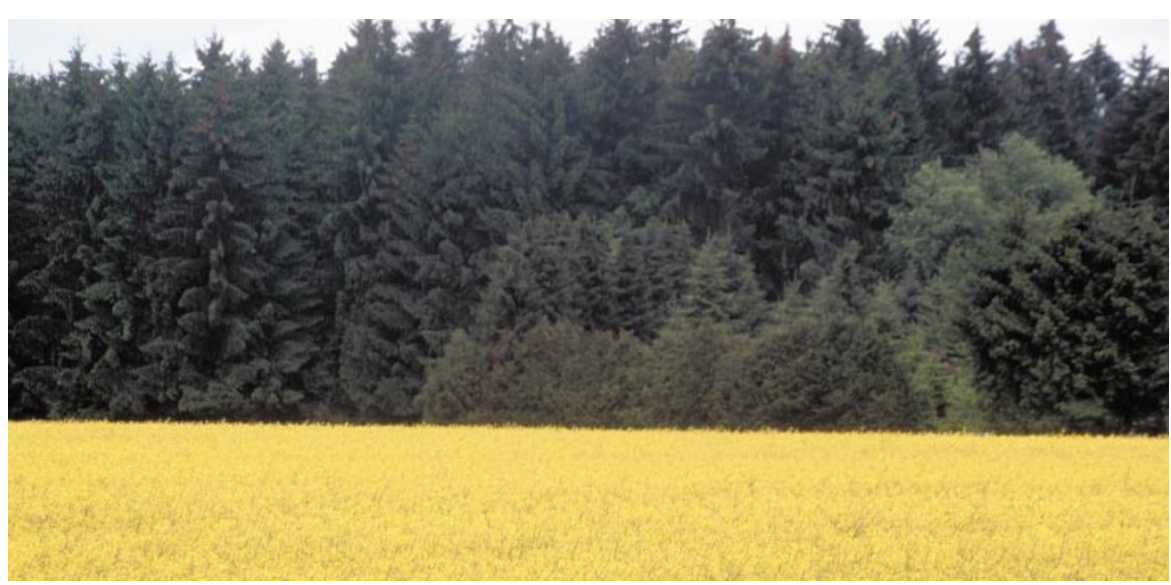

No hiding place: new rules could open the way for transgenic tests of crops such as oilseed rape (above).

informed about which farms are growing the plants. Details of the experimental use of GM plants will also be made public. The plants will initially be approved for use for a maximum period of ten years, after which a renewed application must be made.

The directive also addresses concerns that GM organisms may spread resistance to antibiotics. Organisms containing antibioticresistance genes, widely used as genetic markers, must be phased out by 2004 for GM plants put on the market and by 2008 for GM organisms used experimentally.

The directive was adopted after being approved last week by the European Parliament. But the nations behind the de facto moratorium - France, Italy, Greece, Denmark, Austria and Luxemburg - reaffirmed their intention to block GM crops altogether.

The six states called for extra rules on the traceability and labelling of GM products,

\section{Wheels start to turn for mutant mouse archive}

\section{Alison Abbott, Munich}

After a somewhat shaky start, the European Mouse Mutant Archive (EMMA) is at last preparing to expand. With a grant from the European Commission, the archive is set to become an important source of mouse models for biologists.

The 500,000 euros (US\$460,000) awarded to the archive by the commission will allow EMMA to improve its organization and start a new database of mouse strains.

EMMA is a collaboration between its main site at Monterotondo near Rome and branches in Germany, France, Sweden, Britain and Portugal. The new database will be housed at the European Bioinformatics

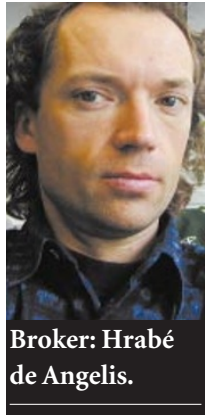

Institute near Cambridge. It will interface with a database at the Jackson Laboratory in Maine, currently the main source of mutant mouse strains worldwide. EMMA's archive is available free to all academics, and the mice cost 200 euros per strain. EMMA has had a difficult birth, typifying the problems that can beset cross-European ventures. It struggled to open at all in 1999, after failing to win sufficient support from either national governments or the European
Commission (see Nature 402, 4; 1999). So far it has archived only about 100 mouse strains. But its star appears to be rising following the appointment last autumn of its first director, Martin Hrabé de Angelis, of the Institute for Experimental Genetics at the GSF national research centre in Munich. Hrabé de Angelis has brokered an agreement between EMMA's sites to archive another 650 mouse strains over the next three years.

But EMMA's long-term funding is uncertain. The European Commission's sixth Framework programme for research has so far made no commitment to funding for existing research infrastructures.

www.emma.rm.cnr.it 
and they also want the commission to set up a system concerning environmental liability to supplement the existing regulatory framework for plant biotechnology.

The industry gave the directive a cautious welcome, despite its rigour. "It will provide the necessary transparency to restore public confidence in the safety of GM products," says Simon Barber, director of the plant biotechnology unit at EuropaBio, the European Association for Bioindustries. "This is an important step towards the end of the moratorium and it will hopefully enable us eventually to sell our products in Europe."

"We understand the demand from society for greater rigour," says Barber. But he warns that over-regulation of plant biotechnology could hinder innovation and put plant geneticists in Europe at a competitive disadvantage.

The moratorium has held up 14 applications for the commercial cultivation of GM plants, including maize and oilseed rape varieties developed by Aventis Crop Science, Syngenta and Plant Genetic Systems.

The environmental group Greenpeace called the directive "a massive improvement" on existing regulations. But a spokesman for the group said that it would not justify lifting the moratorium.

\section{Canada's BSE fears 'groundless'}

\section{David Spurgeon, Montreal}

Brazil and Canada moved quickly this week to patch up a row over a Canadian threat to ban Brazilian beef because of fears of bovine spongiform encephalopathy (BSE).

Canada had announced that it would ban imports of Brazilian beef on scientific grounds. But after a barrage of criticism from both countries, the government indicated that the ban was likely to be lifted as suddenly as it had been imposed.

The threat to ban the beef caused uproar in Brazil, and came under fire in Canada after two scientists in the federal health department said publicly that it had no scientific basis and was motivated by politics rather than health concerns.

The Canadian Food Inspection Agency says that the ban was imposed because Brazil failed to supply adequate documentation on cattle it had recently imported from Europe. But critics say the real reason was a longrunning trade dispute between the two countries over aircraft manufacturing subsidies.

The World Trade Organization has ruled that Brazilian subsidies to Embraer, a direct competitor of Canada's Bombardier in the lucrative market for small passenger-jets, are

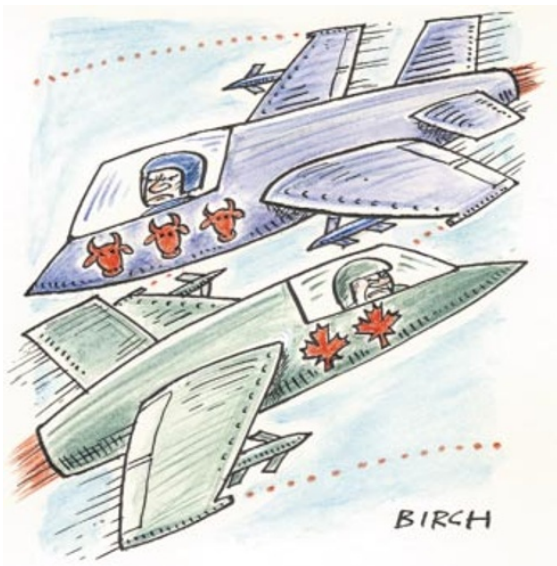

illegal, and that Canada can impose retaliatory trade sanctions. But it has been reluctant to do this, as it regards Brazil as an important regional ally.

In Brazil, where no cases of BSE have been reported, the beef ban was branded a dirty trick in the press.

The mild-mannered Brazilian president, Fernando Henrique Cardoso, warned of a possible trade war with Canada, and the ban sparked public protests and led to Canadian whisky being dumped in the streets of São Paulo.

\section{India promises more earthquake research}

\section{K. S. Jayaraman, New Delhi}

The earthquake that ravaged Gujarat last month has drawn a pledge from the Indian government to increase seismological research and allow participation by foreign scientists.

India has been deeply suspicious of foreign involvement in its earthquake research. Apart from concerns that foreign researchers would use their data to detect Indian nuclear-weapons tests, India had alleged that US researchers abused their access to the Himalayas by attempting to spy on Chinese missile programmes.

And India has previously allowed foreign seismologists to carry out field studies only in collaboration with local scientists. "We don't want to allow outsiders to walk away with data without our people knowing what was collected, and for what purpose," explains Valangiman Ramamurthi, the science secretary.

But after a meeting of India's top scientific administrators, a change of approach was announced last week.

The Himalayas are of great interest to seismologists because they were created by the collision of the Indian and Eurasian tectonic plates, which resulted in the formation

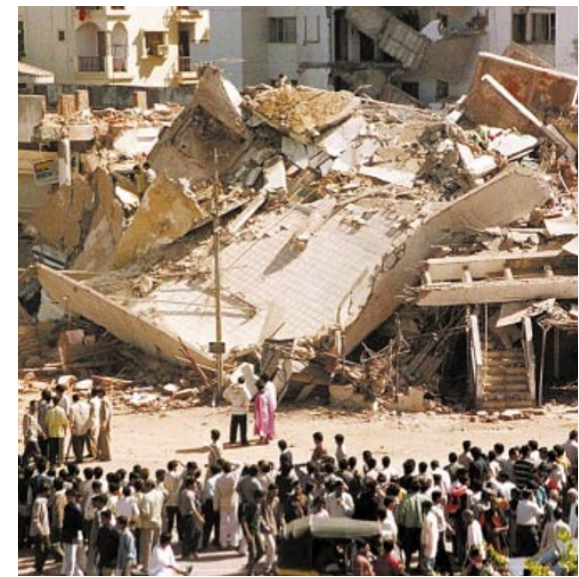

Seismic shock: the Indian government plans to build 40 seismic monitoring stations.

of some two dozen active faults. The Rann of Kutchh, which on 26 January produced the country's worst earthquake in decades, is also of geological interest. But both regions are militarily sensitive.

Access by Western scientists was restricted after an incident in 1974 when it was discovered that a US expedition had left a nuclear-powered sensor on a Himalayan peak so as to spy on Chinese missile launches.
And in 1988, a US gravity survey of the Himalayas was halted after the Indian defence ministry said the data could be used to programme the path of US ballistic missiles flying over the mountain range.

Indian scientists have also been refused access to parts of the Rann of Kutchh including the vast Allah Bund (wall of God) scarp created by an earthquake in 1819 because they lie on the heavily militarized border with Pakistan.

Vinod Gaur, a seismologist with the Centre for Mathematical Modelling and Computer Simulation in Bangalore, welcomed the announcement. "I don't underestimate the security risks near the border, but our attitude should be to encourage important scientific investigations," he says.

Even before the announcement, the Gujarat earthquake seemed to have eased the clampdown on foreign seismologists. Ramamurthi says that more than 30 foreign groups are already studying the aftershocks and other aspects of the earthquake.

The government has also announced a US $\$ 12$ million plan to build 40 seismic monitoring stations in the Himalayas, where it fears the next major earthquake will occur. 